\title{
Peran Kode Etik Atas Pengaruh Akuntansi Forensik, Audit Investigatif dan Data Mining Terhadap Pendeteksian Dugaan Tindak Pidana Pencucian Uang
}

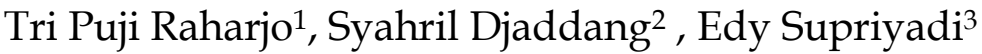 \\ 1,2,3 Universitas Pancasila, Jakarta, Indonesia
}

\section{INFO ARTIKEL JEL Classification :}

M48, M40

\section{Keywords :}

forensic accounting, investigative audit, data mining, ethics code, criminal act of money laundering's detection.

\begin{abstract}
This research aims to examine and analyze the effect of forensic accounting, investigative audit and data mining on detection of criminal act of money laundering's suspicion with the role of ethics code as a moderating factor. The research object are the analyst and examiner of financial transaction of a governmental institution named Pusat Pelaporan and Analisis Transaksi Keuangan (Indonesian Financial Transaction Report and Analysis Centre) with a total of 40 respondents. This research is using nonprobability sampling method. Data analysis is performed using Stuctural Equation Modeling Partial Least Square (SEM-PLS) by using WarpPLS 6.0. The results showed that forensic accounting has significant effect, investigative audit doesn't have effect and data mining doesn't have effect on criminal act of money laundering's suspicion. The role of ethics code moderates the effect of investigative audit on the detection of criminal act of money laundering's suspicion and also moderates the effect of data mining on the detection of criminal act of money laundering's suspicion. The contribution of this research is strengthening and enriching the source of information about the scope of forensic accounting's implementation.
\end{abstract}

\begin{abstract}
ABSTRAK
Tujuan penelitian ini adalah menguji dan menganalisis pengaruh akuntansi forensik, audit investigatif dan data mining terhadap pendeteksian dugaan tindak pidana pencucian uang dengan peran kode etik sebagai variabel pemoderasi. Objek penelitian ini adalah analis dan pemeriksa transaksi keuangan pada Pusat Pelaporan dan Analisis Transaksi Keuangan sebanyak 40 orang. Metode sampling yang digunakan adalah nonprobability sampling. Metode analisis data pada penelitian ini adalah Stuctural Equation Modeling Partial Least Square (SEM-PLS) menggunakan WarpPLS 6.0. Hasil penelitian ini adalah akuntansi forensik berpengaruh signifikan, audit investigatif tidak berpengaruh dan data mining tidak berpengaruh terhadap pendeteksian dugaan tindak pidana pencucian uang. Peran kode etik memoderasi pengaruh audit investigatif terhadap pendeteksian dugaan tindak pidana pencucian uang dan juga memoderasi pengaruh data mining terhadap pendeteksian dugaan tindak pidana pencucian uang.
\end{abstract}




\section{Pendahuluan}

Pada Februari 2015, bahwa Financial Action Task Force (FATF) secara bulat telah mengakui upaya dan komitmen Indonesia dalam mencegah dan memberantas tindak pidana pencucian uang dan pendanaan terorisme, kemudian memutuskan Indonesia keluar dari daftar hitam menjadi greylist country. FATF merupakan organisasi internasional yang berdiri dengan tujuan untuk menerapkan standar internasional dan promosi langkah-langkah efektif dalam mengatasi kejahatan keuangan dengan mengeluarkan 40 rekomendasi terkait anti money laundering dan 9 rekomendasi khusus terkait countering financing terrorism (www.ppatk.go.id).

Keluarnya Indonesia dari daftar hitam, memerlukan upaya dan langkah yang cukup panjang, antara lain melalui perbaikan dari berbagi aspek regulasi, koordinasi dan implementasi dalam rezim anti pencucian uang, pencegahan pendanaan terorisme, dan proliferasi senjata pemusnah massal (www.ppatk.go.id). Dari sisi aspek regulasi adalah lahirnya Undang-undang Nomor 15 Tahun 2002 tentang Tindak Pidana Pencucian Uang kemudian dilakukan revisi terakhir menjadi Undang-undang Nomor 8 Tahun 2010 tentang Pencegahan dan Pemberantasan Tindak Pidana Pencucian Uang.

Revisi undang-undang dilakukan dalam rangka meningkatkan efektifitas penegakan hukum, melalui pendekatan anti pencucian uang (anti-money laundering strategy) dan mengamanatkan kepada Pusat Pelaporan dan Analisis Transaksi Keuangan (PPATK) sebagai focal point Indonesia dalam melaksanakan rezim anti money laundering. PPATK merupakan satu-satunya lembaga intelijen dibidang keuangan, berdasarkan pasal 40 Undang-undang Nomor 8 Tahun 2010 tentang Pencegahan dan Pemberantasan Tindak Pidana Pencucian Uang, mempunyai tugas dan fungsi sebagai berikut : a) melakukan pencegahan dan pemberantasan tindak pidana Pencucian Uang, b) pengelolaan data dan informasi yang diperoleh PPATK, c) pengawasan terhadap kepatuhan Pihak Pelapor dan d) melakukan analisis atau pemeriksaan laporan dan informasi Transaksi Keuangan yang berindikasi tindak pidana
Pencucian Uang dan/atau tindak pidana lain sebagaimana dimaksud dalam Pasal 2 ayat (1).

Berdasarkan Bulletin Statistik tentang Anti Pencucian Uang dan Pendanaan Terorisme PPATK Volume: 105/THN IX/2018 Edisi November 2018, perihal perkembangan dan peningkatan jumlah Laporan Transaksi Keuangan Mencurigakan (LTKM) yang diterima oleh PPATK perbulan November 2017 s.d. November 2018. sebagaimana dalam gambar grafik berikut :

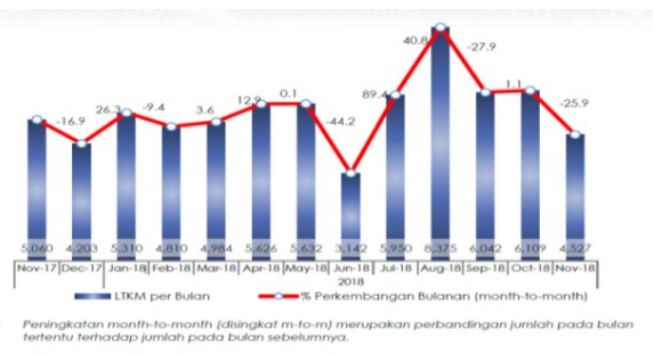

Gambar 1. Perkembangan dan Peningkatan Jumlah LTKM yang Diterima PPATK perbulan November 2017 s.d. November 2018

Dari grafik diatas, dapat disimpulkan bahwa jumlah LTKM yang dilaporkan oleh Penyedia Jasa Keuangan (PJK) dan Penyedia Barang dan Jasa (PBJ) kepada PPATK mengalami kenaikan dan penurunan setiap bulannya cenderung dinamis. Namun, pada bulan Agustus 2018 jumlah LTKM yang dilaporkan mengalami kenaikan signifikan apabila dibandingkan dengan bulan sebelumnya yaitu terjadi kenaikan sebesar $40.8 \%$. Tingginya jumlah LTKM, mengindikasikan bahwa transaksi-transaksi yang dilakukan para nasabah tidak sesuai dengan ketentuan/ profil yang sesungguhnya sehingga potensi terjadinya pelanggaran/tindak pidana.

Bulletin tersebut, juga menyajikan informasi jumlah Hasil Analisis (HA) transaksi keuangan terkait dugaan terjadinya tindak pidana asal dan tindak pidana pencucian uang yang disampaikan kepada Penyidik pada periode 2017 s.d 2018. Jumlah dugaan tindak pidana asal dan tindak pidana pencucian uang yang berhasil diidentifikasi lebih dari 21 (dua puluh satu) jenis tindak pidana. Jenis -jenis tindak pidana tersebut termasuk kategori jenis tindak pidana dengan motif ekonomi seperti korupsi, penipuan, 
penggelapan (fraud). Adapun rinciannya apat dilihat pada tabel dibawah ini :

Tabel 1. Jumlah HA yang disampaikan ke Penyidik berdasarkan dugaan tindak pidana asal tahun 2017 s.d tahun 2018

\begin{tabular}{|c|c|c|c|}
\hline No & Dugaan Tindak Pidana Asal & \begin{tabular}{|c|}
$\begin{array}{c}\text { Kumulatif } \\
\text { sd } 2017\end{array}$ \\
\end{tabular} & $\begin{array}{c}\begin{array}{c}\text { Kumulatif } \\
\text { sd } 2018\end{array} \\
\end{array}$ \\
\hline (l) & (2) & (3) & (4) \\
\hline 1 & Korupsi; & 173 & 221 \\
\hline 2 & Penyuapan; & 13 & 5 \\
\hline 3 & Narkotika; & 24 & 42 \\
\hline 4 & Di Bidang Perbankan; & 5 & 4 \\
\hline 5 & Di Bidang Pasar Modal; & 0 & 0 \\
\hline 6 & Di Bidang Perasuransian; & 0 & 0 \\
\hline 7 & Kepabeanan; & 7 & 10 \\
\hline 8 & Pendanaan Terorisme; & 22 & 20 \\
\hline 9 & Pencurian; & 0 & 0 \\
\hline 10 & Penggelapan; & 14 & 6 \\
\hline 11 & Penipuan; & 42 & 57 \\
\hline 12 & Pemalsuan; & 0 & 6 \\
\hline 13 & Perjudian & 1 & 2 \\
\hline 14 & Prostitusi; & 0 & 0 \\
\hline 15 & Di Bidang Perpajakan; & 39 & 58 \\
\hline 16 & Di Bidang Kehutanan; & 0 & 2 \\
\hline 17 & Di Bidang Kelautan Dan Perikanan; Atau & 2 & 0 \\
\hline 18 & Perdagangan Orang & 6 & 9 \\
\hline 19 & Di Bidang Lingkungan Hidup; & 0 & 0 \\
\hline 20 & $\begin{array}{l}\text { Tindak Pidana Lain Yang Diancam Dengan } \\
\text { Pidana Penjara } 4 \text { (Empat) Tahun Atau Lebih }\end{array}$ & 9 & 5 \\
\hline 21 & Tidak teridentifikasi/dll & 4 & 1 \\
\hline \multicolumn{2}{|c|}{ Jumlah HA } & 361 & 448 \\
\hline
\end{tabular}

Berdasarkan tabel diatas, menunjukan bahwa perbandingan jumlah HA PPATK antara tahun 2017 (361) dan 2018 (448) terus meningkat sebesar 81 persen. Hasil tersebut, mengindikasikan bahwa masih tingginya dugaan terjadinya tindak pidana asal dan tindak pidana pencucian uang.

Dalam proses penyusunan HA tersebut, diperlukan kemampuan mengkombinasikan pemahaman disiplin ilmu akuntansi, hukum dan audit sehingga dalam proses audit mengedepankan untuk mendapatkan buktibukti pelanggaran hukum. Walaupun sebenarnya audit secara umum sebatas untuk menilai tingkat kewajaran laporan keuangan tidak ditujukan secara khusus untuk menemukan kecurangan atau pelanggaran yang berdampak terjadinya kerugian, namun dalam suatu audit dimungkinkan ditemukan suatu kecurigaan terjadinya fraud, pencurian asset atau kecurangan yang bersifat sistematis.

Menurut Tuanakotta (2010 : 351), bahwa penerapan akuntasi forensik dan audit investigatif seperti teknik-teknik yang diterapkan dalam kejahatan perpajakan dan kejahatan terorganisasi (organized crime), follow the money dalam fraud dan pencucian uang, teknik pembuktian hukum, computer forensik dan lain sebagainya. Tujuan penerapan audit investigasif adalah untuk mengumpulkan bukti - bukti yang dapat diterima oleh ketentuan perundang-undangan yang berlaku atau mengumpulkan bukti hukum dan barang bukti sesuai dengan hukum acara dan sebagai pembuktian di persidangan. Auditor forensik yang akan melaksanakan audit investigatif harus memenuhi persyaratan kemampuan dan keahlian.

Sedangkan Owolabi, Dada, dan Olaoye (2013) menambahkan bahwa akuntan forensik dapat menerapkan teknik audit keuangan yang serupa, namun dengan keberatan dan prosedur yang berbeda; dan mungkin memvalidasi perhitungan yang diperlukan dengan meneliti jejak dokumen untuk mencapai tujuan tertentu dari yang tidak taat. Oleh karena itu, penggunaan teknik akuntansi forensik dapat meningkatkan penuntutan kasus kejahatan ekonomi dan keuangan serta menjadi tantangan baru dalam bidang ilmu akuntansi dan hukum.

Sebagai contoh, penerapan atas akuntansi forensik membantu mengungkap terjadinya tindak pidana korupsi dan pencucian uang mantan Ketua Mahkamah Konstitusi pada tahun 2013. "PPATK: Aliran Dana Akil Mochtar Lebih dari Rp 10Miliar" , disampaikan bahwa terdapat sejumlah kejanggalan dalam transaksi yang dilakukan CV. RS telah terendus KPK dan PPATK. Kejanggalan tersebut, antara lain sejak berdiri tahun 2010 bahwa CV. RS tercatat tak pernah mengeluarkan biaya operasional layaknya badan usaha yang normal, tetapi terus-menerus ada aliran dana masuk. Jumlah aliran dana yang masuk ke dua rekening Bank BUMN atas nama CV. RS bahkan mencapai $\mathrm{Rp} 100$ miliar (kompas.com 16/10/2013).

Kondisi tersebut, menggambarkan bahwa disiplin ilmu akuntansi forensic dan pemanfataan data informasi transaksi keuangan dari Penyedia Jasa Keuangan yang dilaporkan kepada PPATK dapat dilakukan analisis untuk mendeteksi terjadinya dugaan tindak pidana pencucian uang. Dalam melakukan pendeteksian tersebut, juga diperlukan adanya integritas dengan menjaga etika profesi. Menurut Abdul Halim (2008: 29) mengungkapkan etika profesional meliputi sikap para anggota profesi agar idealistis, praktis dan realistis. Dalam rangka 
efektivitas pelaksanaan terhadap etika profesi maka diperlukan sebuah peraturan kode etik. Peraturan kode etik berisi tentang ketentuan-ketentuan mendasar yang mengatur tentang perilaku dan hak/ kewajiban seseorang yang mempunyai profesi. Kode etik, bertujuan untuk menghindari terjadinya conflict of interest dan penyimpangan-penyimpangan serta untuk menjaga kualitas hasil audit yang objektif.

Sehubungan dengan uraian diatas, maka kiranya penting bagi peneliti untuk melakukan penelitian dengan judul "Peran Kode Etik Atas Pengaruh Akuntansi Forensik, Audit Investigatif Dan Data Mining Terhadap Pendeteksian Dugaan Tindak Pidana Pencucian Uang”.

\section{Telaah Teori dan Pengembangan Hipotesis}

\section{Teori Fraud Pentagon}

Teori fraud pentagon merupakan perluasan dari teori fraud triangle yang sebelumnya dikemukakan oleh Cressey (Crowe, 2011), dalam teori ini menambahkan dua elemen fraud lainnya yaitu kompetensi (competence) dan arogansi (arrogance). 5 (lima) unsur yang menjadi penyebab terjadinya fraud sebagai berikut:

a. Pressure (tekanan), salah satu penyebab terjadinya fraud karena adanya tekanan. Manajemen atau pegawai akan merasakan sebuah tekanan untuk melakukan kecurangan dikarenakan adanya pengaruh gaya hidup, kebutuhan ekonomi dan tekanan dari pihak lain seperti atasan yang mendorong seseorang untuk melakukan fraud sebagai jalan pintas.

b. Oppottunity (kesempatan), kesempatan untuk melakukan kecurangan muncul antara lain disebabkan karena lemahnya pengendalian internal, adanya system pengawasan yang tidak jelas, terjadi duplikasi jabatan yang membuka kewenangan lebih sehingga potensi bagi manajemen atau pegawai untuk melakukan fraud.

c. Rationalization (rasionalisasi), merupakan kondisi berupa sikap, karakter atau serangkaian nilai-nilai etis yang seolah -olah membolehkan manajemen atau pegawai untuk melakukan tindakan yang tidak jujur atau mereka berada dalam lingkungan yang aman. Kondisi tersebut mucul secara berulang karena apabila ditemukan dan terbukti terjadi kecurangan sanksi yang diberikan oleh manajemen kepada para pelaku fraud hanya berupa teguran administrasi sehingga tidak memberikan efek jera.

d. Competence (kompetensi), kompetensi/kapabilitas merupakan kemampuan karyawan untuk mengabaikan kontrol internal, mengembangkan strategi penyembunyian, dan mengontrol situasi sosial untuk keuntungan pribadinya.

e. Arrogance (arogansi) adalah sikap superioritas atas hak yang dimiliki dan merasa bahwa kontrol internal atau kebijakan perusahaan tidak berlaku untuk dirinya

\section{Akuntansi Forensik}

Akuntansi Forensik adalah akuntansi yang akurat (cocok) untuk tujuan hukum. Artinya, akuntansi yang dapat bertahan dalam kancah perseteruan selama proses pengadilan, atau dalam proses peninjauan judicial atau administratif' (imagama.feb.ugm.ac.id)

Merriam Webster's Collegiate Dictionary (edisi ke 10) dapat diartikan "berkenaan dengan pengadialan" atau "berkenaan dengan penerapan pengetahuan ilmiah pada masalah hukum". Oleh karena itu akuntasi forensik dapat diartikan penggunaaan ilmu akuntansi untuk kepentingan hukum. Akuntansi forensik adalah akuntansi yang akurat untuk tujuan hukum selama proses pengadilan atau dalam proses peninjauan yudisial atau tinjauan administratif. Dalam penerapan akuntansi forensik, akan diaplikasikan sebuah keterampilan investigasi dan analitik yang bertujuan untuk memecahkan masalahmasalah keuangan melalui cara-cara yang sesuai dengan standar yang ditetapkan oleh pengadilan atau hukum.

Tuanakotta (2010: 18), menjelaskan bahwa akuntansi forensik pada awalnya adalah perpaduan yang paling sederhana antara akuntansi dan hukum disimpulkan bahwa akuntansi forensik merupakan penerapan disiplin akuntansi, hukum dan teknik investigatif untuk melakukan penelusuran aset, penghitungan kerugian keuangan negara dan asset recovery sehingga 
dapat digunakan dalam penyelesaian hukum baik di dalam atau diluar pengadilan.

\section{Audit Investigatif}

Audit inivestigatif merupakan jenis audit atau pemeriksaan yang dilakukan oleh pemeriksa dengan menitik beratkan untuk mendapatkan bukti -bukti adanya indikasi atau dugaan terjadinya pelanggaran pidana baik di sector maupun swasta. Pendekatan yang dilakukan dalam audit investigasi adalah melalui kesamaan antara tehnik auditing dengan hukum. Menurut Tuanakotta (2010:116) merumuskan beberapa standar dalam melakukan investigasi sebagai contoh investigasi untuk mendeteksi dugaan fraud.

Penerapan dan standar audit investigatif ini dijelaskan dalam konteks Indonesia :

a. Seluruh investigasi harus di landasi praktek - praktek terbaik yang diakui (accepted best practise). Istilah best practise sering dipakai dalam penetapan standart dalam istilah ini tersirat dua hal yaitu adanya upaya membandingkan antara praktek-praktek yang ada dengan merujuk kepada yang terbaiik saat itu, dan upaya benchmarking dilakukan terus menerus untuk mencari solusi terbaik.

b. Mengumpulkan bukti-bukti dengan prinsip-prinsip kehati-hatian (due care) sehingga bukti-bukti tersebut dapat diterima di pengadilan.

c. Memastikan bahwa seluruh dokumentasi dalam keadaan aman terlindungi, dan di index; dan jejak audit tersedia. Dokumentasi ini diperlukan sebagai referensi apabila ada penyelidikan di kemudian hari untuk memastikan bahwa investigasi sudah dilakukan dengan benar. Referensi ini juga membantu perusahaan dalam upaya perbaikan cara-cara investigasi sehingga accepted best practices yang dijelaskan diatas dapat dilaksanakan.

d. Memperhatikan bahwa para investigator mengerti akan hak asasi pegawai dan senantiasa menghormatinya. Kalau investigasi dilakukan dengan cara yang melanggar hak asasi pegawai, yang bersangkutan dapat menuntut perusahaan dan investigatornya. Bukti-bukti yang sudah dikumpulkan dengan waktu dan biaya yang banyak menjadi sia-sia. e. Mengingat bahwa beban pembuktian ada pada perusahaan yang "menduga" pegawainya melakukan kecurangan, dan pada penuntut umum yang mendakwah pegawai tersebut, baik dalam kasus hukum administratif and pidana.

f. Mencakup seluruh substansi investigasi dan "kuasai" seluruh target yang sangat kritis ditinjau dari segi waktu.

g. Meliputi seluruh tahapan kunci dalam proses investigasi, termasuk perencaaan, pengumpulan bukti, dan barang bukti, wawancara, kontak dengan pihak ke tiga, pengamanan yang bersifat rahasia, ikuti tata cara atau protokol, dokumentasi dan penyelenggaraan catatan, keterlibatan polisi, kewajiban hukum, dan persyaratan mengenai pelaporan.

\section{Data Mining}

Data mining adalah the extraction of hidden predictive information from large databes yang berarti bahwa penambangan data. Penambangan data dilakukan dengan cara mengekstraksi data besar yang tersembunyi sehingga data tersebut dapat digunakan untuk memprediksi.

Arus Tuanakotta (2010 : 478) definisi sederhana, dari data mining terdiri dari beberapa unsur sebagai berikut :

a. Ada sesuatu yang diekstraksi atau ditarik ke permukaan. Ini tidak berbeda dengan extraction pada pertambangan pada umumnya, seperti ada pertambangan emas, tembaga, perak, dan lain-lain

b. Yang diekstrak adalah hidden predictive information atau informasi tersembunyi yang bersifat prediktif. Kemampuan mengekstraksi informasi separti inilah yang membuat data mining suatu teknologi yang sangat ampuh, misalnya sebagai alat marketing dan alat investigasi.

Data yang ditambang ini berada dalam data bases yang sangat besar. Sebagai contoh seperti data base yang berisi semua kendaraan bermotor di Indonesia, lengkap dengan segala macam informasi lainnya. Pengungkapan kasus Bom Bali I yang dilakukan oleh Polri bahwa bermula dari serpihan mesin kendaraan yang digunakan dalam pengeboman, data base ini dapat mengungkapkan pabrik pembuat mesin dan tahun pembuatan. Setelah itu, kepolisian dapat menelusuri dari pemilik 
awal sampai pemilik terakhir yang terdaftar dengan alamatnya.

\section{Kode Etik}

Tuanakotta (2010 : 107), para akuntan dan praktisi hukum mengenal kode etik. Sebagaimana kode etik merupakan bagian yang tidak terpisahkan dari kehidupan berprofesi selain itu kode etik juga mengatur hubungan antara profesi dengan sesamanya dengan pemakai jasanya dan stakeholder lainya dan dengan masyarakat secara luas. Kode etik juga berisi nilai-nilai luhur yang penting bagi eksistensi profesi. Beberapa hal terkait dengan kode etik adalah integritas, hormat, independent dan jujur.

Kode etik dalam Peraturan Kepala Pusat Pelaporan Dan Analisis Transaksi Keuangan Nomor: PER-05A/ 1.01/PPATK/08/10 Tentang Kode Etik Pegawai Pusat Pelaporan Dan Analisis Transaksi Keuangan (PPATK, 2010) dalam rangka menjaga citra, dan kredibilitas PPATK dalam melaksanakan fungsi, tugas, dan wewenangnya diperlukan kode etik pegawai yang sejalan dengan nilainilai dasar yang dikembangkan di PPATK. Kode etik, bertujuan untuk:

a. Menjaga citra dan kredibilitas PPATK melalui penciptaan dan pelaksanaan tatakerja yang jujur dan transparan sehingga mendorong peningkatan kinerja;

b. Membina karakter dan watak Pegawai, memelihara rasa persatuan dan kesatuan sehingga terwujud kerjasama dan semangat dalam pelaksanaan pencegahan dan pemberantasan pidana pencucian uang; dan

c. Mendorong etos kerja Pegawai untuk mewujudkan Pegawai yang profesional dan sadar akan tanggungjawabnya.

Berdasarkan Keputusan Kepala Pusat Pelaporan Dan Transaksi Keuangan Nomor : KEP - 1/1.01/PPATK/ 01/08, memuat tentang definisi nilai-nilai dasar kode etik yang harus dijunjung tinggi oleh pegawai PPATK yaitu:

a. Integritas

Integritas merupakan nilai yang menggambarkan kejujuran terhadap segala aspek dalam pelaksanaan fungsi dan tugasnya serta konsisten dengan etika dan nilai-nilai dasar organisasi, dapat dipercaya dan mematuhi peraturan perundang-undangan yang berlaku dalam rangka melaksanakan fungsi dan tugas
PPATK dan meningkatkan kepercayaan para pemangku kepentingan terhadap PPATK, tidak melakukan tindakan yang melawan hukum dan tercela, serta memberikan respek dan kontribusi terhadap tujuan yang telah ditetapkan sesuai etika dan perundang-undangan.

b. Tanggung Jawab

Tanggung jawab terkait erat dengan amanah dan merupakan nilai yang menggambarkan pelaksanaan kewajibannya sesuai dengan kewenangan, peran, fungsi dan tugas sebagaimana diamanatkan peraturan perundangundangan. Kepatuhan dan konsistensi pelaksanaan kegiatan sesuai dengan peraturan perundang-undangan akan mendorong kesinambungan kegiatan, meningkatkan pengakuan dan kepercayaan pemangku kepentingan serta menghindarkan adanya penyalahgunaan wewenang.

c. Profesionalisme

Profesionalisme merupakan nilai yang mengutamakan kecakapan terhadap kompetensi baik dibidang pengetahuan, ketrampilan, pengalaman serta peningkatan diri yang berkelanjutan, memiliki dan melaksanakan komitmen, serta melaksanakan etika organisasi dan mematuhi peraturan perundang-undangan yang berlaku.

d. Kerahasiaan

Kerahasiaan merupakan nilai yang mengutamakan kehati-hatian dan perlindungan terhadap informasi dan atau asset yang diperoleh dan/atau digunakan dalam melaksanakan peran, fungsi dan tugas intelijen keuangan sesuai dengan peraturan perundang-undangan.

e. Kemandirian.

Kemandirian merupakan sikap dan tindakan yang menggambarkan independensi dan tidak memihak dalam menjalankan fungsi dan tugas PPATK serta penegakkan hukum.

\section{Pendeteksian dugaan tindak pidana pencucian uang}

Yunus Husein (2007:10), money laundering atau pencucian uang didefinisikan sebagai perbuatan memindahkan, menggunakan, atau melakukan perbuatan lainnya atas hasil dari suatu tindak pidana 
yang seringkali dilakukan oleh organized crime, maupun individu yang melakukan tindakan korupsi, perdagangan narkotika, kejahatan di bidang perbankan, pasar modal dan tindak pidana lainnya dengan tujuan menyembunyikan atau mengaburkan asalusul uang yang berasal dari hasil tindak pidana tersebut, sehingga dapat digunakan karena seolah-olah tampak sebagai uang yang sah tanpa terdeteksi bahwa aset tersebut berasal dari kegiatan yang ilegal.

Pendapat lain dikemukakan oleh Pamela H. Bucy dalam buku yang berjudul White Collar Crime : Case and Meterials, definisi "money laundering" yang dituangkan di buku Adrian Sutedi (2008 : 14) sebagai berikut :

"Money laundering is the concealment of the existence, nature illegal source of illicit fund in such a manner that the funds will appear legitimate if discovered".

Di Indonesia pencucian uang merupakan jenis tindak pidana, dimana tindak pidana dimaksud didahului dengan adanya predicate crime, berdasarkan Pasal 2 UU No 8 Tahun 2010 tentang Pencegahan dan Pemberantasan tindak Pidana Pencucian Uang yaitu terdapat 26 (dua puluh enam ) jenis tindak pidana asal. Menurut Adrian Sutedi (2008:18) terdapat tahap -tahap dan proses melakukan usaha pencucian uang yaitu:

a. Placement yaitu tahap pertama dari pencucian uang dengan menempatkan (mendepositokan) uang haram yang bersumber dari hasil kejahatan tersebut ke dalam sistem keuangan (financial system) seperti Bank, Asuransi.

b. Layering yaitu memisahkan hasil tindak pidana dari sumbernya melalui berbagi tahap transaksi keuangan sehingga menjadi semakin sulit dan membutuhkan peningkatan kemapuan secara sistematis dan berkesinambungan.

c. Integration adalah upaya menggunakan harta kekayaan yang telah tampak sah, baik untuk dinikmati langsung, diinvestasikan kedalam berbagi bentuk kekayaan materiil atau keuangan, dipergunakan untuk membiayai kegiatan bisnis yang sah, maupun untuk membiayai kembali kegiatan tindak pidana.

Dalam melakukan tindak pidana pencucian uang tersebut, para pelaku tidak terlalu mempertimbangkan hasil yang akan diperoleh dan besarnya biaya yang akan dikeluarkan, karena tujuan utamanya untuk menyamarkan asal usul sumber dana dari hasil kejahatan sehingga akhirnya dapat dinikmati dengan aman. Menurut Yudi Kristiana (2015 :20) sebagaimana menindaklajuti hal tersebut dan operasionalisasi UU No 8 tahun 2010 maka perlu pemahaman beberapa legal term terkait dengan deteksi terjadinya tindak pidana pencucian uang yaitu dengan melakukan pemeriksaan yang terdiri dari :

a. Identifikasi masalah,

b. Analisis dan

c. Evaluasi transaksi keuangan yang mencurigakan (LTKM).

\section{Hipotesis Penelitian :}

H1 : akuntansi forensik berpengaruh terhadap pendeteksian dugaan tindak pidana pencucian uang

$\mathrm{H} 2$ : audit investigatif berpengaruh terhadap pendeteksian dugaan tindak pidana pencucian uang

$\mathrm{H} 3$ : data mining berpengaruh terhadap pendeteksian dugaan tindak pidana pencucian uang

H4 : Kode etik memoderasi pengaruh audit investigatif terhadap pendeteksian dugaan tindak pidana pencucian uang

H5 : Kode etik memoderasi pengaruh data mining terhadap pendeteksian dugaan tindak pidana pencucian uang.

\section{Metode Penelitian}

Populasi adalah wilayah generalisasi yang terdiri atas : objek/ subjek yang mempunyai kuantitas dan karakteristik tertentu yang ditetapkan oleh peneliti untuk dipelajari dan kemudian ditarik kesimpulannya. Teknik sampling dalam penelitian ini menggunakan nonprobability sampling yaitu teknik pengambilan sampel yang tidak memberi peluang/ kesempatan sama bagi setiap unsur atau anggota populasi untuk memilih menjadi sampel atau disebut dengan istilah pengambilan sampling total yaitu populasi sebagai sampel. Sampel yang dijadikan sebagai responden adalah para Analis dan Pemeriksa Transaksi Keuangan PPATK. Variabel dependen adalah variabel yang dipengaruhi atau yang menjadi akibat karena adanya variabel bebas. Dalam penelitian ini 
variabel dependentnya adalah pendeteksian dugaan tindak pidana pencucian uang. Variabel independen adalah variabel yang mempengaruhi atau yang menjadi sebab perubahannya atau timbulnya variabel dependen (terikat). Maka dalam penelitian ini yang menjadi variabel independen adalah akuntansi forensik, audit investigatif, dan data mining. Variabel pemoderasi adalah variabel yang mempengaruhi memperkuat dan memperlemah hubungan antara variabel independent dan dependent. Maka dalam penelitian ini yang menjadi variabel pemoderasi adalah kode etik.

\section{Operasionalisasi Variabel \\ Variabel Independen dengan Variabel Moderating}

Variabel moderasi adalah salah satu jenis variabel yang memiliki kemampuan dalam memperkuat atau bahkan memperlemah suatu hubungan secara langsung yang terjadi antara variabel independen dengan variabel dependen. Metode ini dilakukan dengan menambahkan variabel perkalian antara variabel independen dengan variabel moderatingnya, sehingga persamaan umumnya adalah sebagai berikut:

$$
\mathrm{Y}=\mathrm{a}+\mathrm{b} 1 \mathrm{X} 1+\mathrm{b} 2 \mathrm{X} 2+\mathrm{b} 3 \mathrm{X} 1 \mathrm{X} 2
$$

\section{Tabel 2. Klasifikasi Jenis Moderasi}

\begin{tabular}{|c|c|c|c|}
\hline No & Easil Uji & Jenis Moderasi & Keterangab \\
\hline 1. & $\begin{array}{l}\dot{b}_{2} \text { noni significant } \\
\dot{b}_{3} \text { significanil }\end{array}$ & 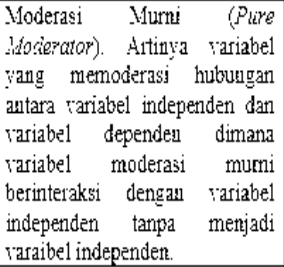 & $\begin{array}{l}b_{i}-b \hat{3} \text { merupakan } \\
\text { koefisien regresi } \\
\text { (nilai peningkatan } \\
\text { atau penluinnan) }\end{array}$ \\
\hline 2 & $\begin{array}{l}\dot{b}_{2} \text { significanil } \\
\dot{y}_{3} \text { significanil }\end{array}$ & $\begin{array}{lcr}\text { Moderasi Semu } & \text { (Ouasi } \\
\text { itocierator). Quasi moderasi } \\
\text { merupakan rariabel yang } \\
\text { memoderasi lubungan antara } \\
\text { rariabel independen dengan } \\
\text { rariabel dependen yang } \\
\text { sekaligus menjadi rariabel } \\
\text { independen. }\end{array}$ & \\
\hline 3. & $\begin{array}{l}\dot{y}_{2} \text { significanit } \\
\dot{b}_{3} \text { noni significant }\end{array}$ & $\begin{array}{l}\text { Prediktor Moderasi (Predictor } \\
\text { 1focieraci Jariabei). Antinya } \\
\text { yariabel moderasi ini hanya } \\
\text { berperanan sebagai ariabel } \\
\text { prediktor (independen) dalam } \\
\text { model bubungan yang dibentuk }\end{array}$ & \\
\hline 4. & $\begin{array}{l}\dot{b}_{2} \text { noni significant } \\
b_{3} \text { non significant }\end{array}$ & 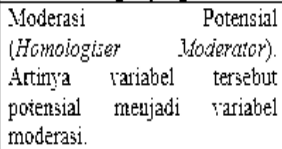 & \\
\hline
\end{tabular}

\section{Analisis PLS-SEM}

PLS-SEM terdapat tahapan dan setiap tahapan akan berpengaruh terhadap tahapan selanjutnya.

a. Konseptualisasi Model menentukan dimensionalitasnya untuk masing-masing.

b. Metode Analisis Alogarithm

menetukan jumlah populasi yang harus dipenuhi.

c. Metode Resampling

resampling jackknifing mengatasi masalah yang terkait dengan kehadiran outlier karena kesalahan dalam pengumpulan data.

d. Diagram Alur

Model Persamaan Penelitian

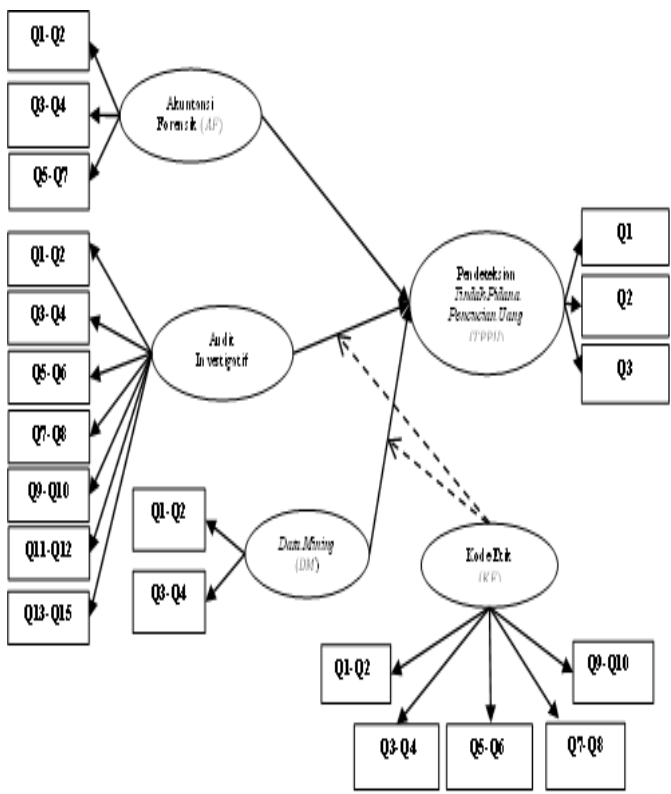

Diagram Alur dalam Persamaan: $T P P U=\alpha+b_{1} \cdot A F+b_{2} \cdot A I+b_{3} \cdot D M+b_{4}(K E \cdot A I)+b_{5}(K E \cdot D M)+e$

Keterangan:

$$
\begin{array}{ll}
\text { TPPU } & =\text { Pend eteksian TPPU } \\
\alpha & =\text { konstanta } \\
e & =\text { eror } \\
\text { AK } & =\text { Akuntasi Forensik } \\
\text { AI } & =\text { Audit Inv estigatif } \\
\mathrm{DM} & =\text { Data Mining } \\
\mathrm{KE} & =\text { Kode Etik } \\
\mathrm{b}_{1}-\mathrm{b}_{5} & =\text { Koefisien regr esi }
\end{array}
$$

e. Evaluasi Model

Evaluasi model pengukuran atau outer model dengan indikator reflektif dapat dilakukan melalui indikator reliability, 
internal consistency reliability, convergent validity dan discriminant validity.

Ringkasan Rule Of Thumb Evaluasi Outer Model:

\begin{tabular}{|c|c|c|}
\hline Kriteria & Parameter & Rule of Thumb \\
\hline Indikator Reliabilin & Loading Factor & $\begin{array}{l}>0.7 \text { untuk confirmanory research } \\
0.6-0.7 \text { masih dapat diterima uutuk } \\
\text { exploraton research }\end{array}$ \\
\hline $\begin{array}{l}\text { Internal Cosnsitency } \\
\text { Reliability }\end{array}$ & $\begin{array}{l}\text { Composite } \\
\text { Relicbility: }\end{array}$ & $\begin{array}{l}>0.7 \text { untuk confrnmenory research } \\
0.6-0.7 \text { masih dapat diterima untuk } \\
\text { exploroton resench }\end{array}$ \\
\hline Convergent Validity & $\begin{array}{l}\text { Average Variance } \\
\text { Exfracted }\end{array}$ & $\begin{array}{l}0.05 \text { untuk confinmatory } d a n \\
\text { exploraton research }\end{array}$ \\
\hline Discriminent Volidity: & $\begin{array}{l}\text { Akar kuadrat AVE } \\
\text { dan korelasi antar } \\
\text { kontruk laten }\end{array}$ & $\begin{array}{l}\text { Akar kuadrat AVE korelasi antar } \\
\text { kontruk laten }\end{array}$ \\
\hline
\end{tabular}

Ringkasan Rule Of Thumb Evaluasi Inner Model :

\begin{tabular}{|c|c|}
\hline Kriteria & Rule of Thumb \\
\hline Adjusted $\mathrm{R}^{2}$ & $\begin{array}{l}\leq 0.70 \text { (kuat), } \leq 0.45 \text { (moderate) } \leq \leq 0.25 \\
\text { (lemah) }\end{array}$ \\
\hline Arerage Path Coefficient (APC) & P. VALLE $\leq 0.05$ \\
\hline Average R square (ARS) & P. VALLE $\leq 0.05$ \\
\hline $\begin{array}{l}\text { Average Adjusted R square } \\
\text { (AARS) }\end{array}$ & P. VALLE $\leq 0.05$ \\
\hline Average Block VIF (AVIF) & $\leq 3.3$ namun nilai $\leq 5$ masih dapat diterima \\
\hline $\begin{array}{l}\text { Average Full Collinearity VIF } \\
\text { (AFVI) }\end{array}$ & $\leq 3.3$ namun nilai $\leq 5$ masih dapat diterima \\
\hline Tenenhaus $\mathrm{GoF}(\mathrm{GoF})$ & $\begin{array}{l}\geq 0.10 \text { (kecil), } \geq 0.25 \text { (menengah), } \geq 0.36 \\
\text { (besar) }\end{array}$ \\
\hline Sympson's Paradox Ratio (SPR) & $\begin{array}{l}\text { Idealnya }=1 \text {, namun nilai } \geq 0.7 \text { masih } \\
\text { dapat diterima }\end{array}$ \\
\hline $\begin{array}{l}\text { R square Contribution Ratio } \\
\text { (RSCR) }\end{array}$ & $\begin{array}{l}\text { Idealnya }=1 \text {, namun nilai } \geq 0.9 \text { masih } \\
\text { dapat diterima }\end{array}$ \\
\hline Statistical Suppression Ratio (SSR) & $\begin{array}{l}\text { Idealnya }=1 \text {, namun nilai } \geq 0.7 \text { masih } \\
\text { dapat diterima }\end{array}$ \\
\hline $\begin{array}{l}\text { Nonlinear birariate causality } \\
\text { direction ratio (NLBCDR) }\end{array}$ & $\begin{array}{l}\text { Idealnya }=1 \text {, namun nilai } \geq 0.7 \text { masih } \\
\text { dapat diterima }\end{array}$ \\
\hline $\mathrm{Q}^{2}$ Predictive relevance & $\begin{array}{l}\mathrm{Q}^{2}>0 \text { (mempunyai predictive relevance) } \\
\mathrm{Q}^{2}<0 \text { (tidak mempunyai predictive } \\
\text { relevance) }\end{array}$ \\
\hline
\end{tabular}

\section{Pengujian Hipotesis}

\section{Uji Validitas}

Uji validitas yang digunakan dalam penelitian ini adalah Civariate Pearson (Produk Momen Pearson) yang dianalisis dengan cara mengkorelasikan masing-masing skor item dengan skor total.

formula koefisien korelasi product moment dari Karl Pearson yaitu :

$$
\begin{aligned}
& r_{x . y} \\
& =\frac{N \Sigma X Y-\Sigma X . \Sigma Y}{\sqrt{\left(N \Sigma x^{2}-(\Sigma X)^{2}\right)\left(N \Sigma Y^{2}-(\Sigma Y)^{2)}\right.}}
\end{aligned}
$$

\section{Uji Reliabilitas}

Uji reliabilitas instrumen dilakukan dengan tujuan untuk mengatahui konsistensi dari instrument sebagai alat ukur sehingga hasil suatu pengukuran dapat dipercaya.
Formula yang digunakan untuk menguji reliabilitas intrumen :

$$
r_{11}=\left[\frac{k}{k-1}\right]\left[1-\frac{\sum \sigma_{t}^{2}}{\sigma \frac{2}{t}}\right]
$$

dimana :

$$
\text { Rumus Varians }=\sigma^{2}=\frac{\Sigma x^{2}-\frac{(\Sigma \mathrm{x})^{2}}{N}}{N}
$$

Keterangan :

$\mathrm{r}_{11}=$ Reliabilitas instrument $/$ koefisien alfa

$\mathrm{k}=$ Banyaknya butir soal.

\section{Uji Parsial}

Uji parsial digunakan untuk menguji ada tidaknya pengaruh dari variabel independen terhadap variabel dependen secara parsial. Rumus pada uji t adalah:

$$
\begin{aligned}
& t=\frac{\partial}{S D \partial / \sqrt{n}} \\
& \partial \quad \begin{array}{l}
\text { = rata-rata deviasi (selisih sampel } \\
\text { sebelum dan sampel sesudah) }
\end{array} \\
& \mathrm{SD} \partial=\text { standar deviasi dari } \partial \\
& \mathrm{n} \quad=\text { banyaknya sampel }
\end{aligned}
$$

\section{Uji Interaksi}

Uji interaksi dilakukan untuk mengetahui variabel moderasi dalam memperkuat atau

\begin{tabular}{|c|c|c|c|c|c|c|}
\hline Yo & Yariabel Penelitian & $\mathrm{Y}$ & Mlin & Max & Iean & $\begin{array}{c}\text { Standar } \\
\text { Dexiation }\end{array}$ \\
\hline 1 & $\begin{array}{l}\text { Akuntansi Forensik } \\
\left(\mathrm{X}_{\mathrm{l}}\right)\end{array}$ & 40 & 3.286 & 5.000 & 4.579 & 0,562 \\
\hline 2 & $\begin{array}{l}\text { Audit Inץestigatif } \\
\left(\mathrm{X}_{2}\right)\end{array}$ & 40 & 3.133 & 5.000 & 4.482 & 0,606 \\
\hline 3 & Data -fining $\left(\mathrm{X}_{\mathrm{j}}\right)$ & 40 & 3.000 & 5.000 & 4.550 & 0.588 \\
\hline 4 & $\begin{array}{l}\text { Pendeteksian TPPU } \\
\text { (I) }\end{array}$ & 40 & 3.667 & 5.000 & 4.525 & 0,563 \\
\hline 5 & Kode Etik ( $\mathrm{M}$ ) & 40 & 3.700 & 5.000 & 4.645 & 0,489 \\
\hline
\end{tabular}
memperlemah hubungan antara variabel independen dengan variabel dependen.

\section{Hasil Penelitian dan Pembahasan}

\section{Hasil Uji Statistik Deskriptif}

Statistik deskriptif dapat dilihat dari nilai rata-rata (mean). Standar deviasi, nilai maksimum dan nilai minimum (Ghozali, 2007). 

Investigatif dan Data Mining Terhadap Pendeteksian Dugaan Tindak Pidana Pencucian Uang

Dapat dilihat bahwa ada tiga jenis variabel yaitu independent, dependent dan moderasi. Variabel independent terdiri dari akuntansi forensik, audit investigatif dan data mining, variabel dependentnya adalah pendeteksian dugaan tindak pidana pencucian uang dan untuk variabel moderasinya adalah kode etik.

\section{Hasil Uji Outner Model}

Evaluasi outer model dilakukan untuk mengetahui validitas dan reliabilitas suatu indikator yang diuji. Variabel unobserved pada penelitian ini adalah Akuntansi Forensik $\left(\mathrm{X}_{1}\right)$, Audit Investigatif $\left(\mathrm{X}_{2}\right)$, Data Mining $\left(\mathrm{X}_{3}\right)$, Kode Etik (M) dan Pendeteksian dugaan tindak pidana pencucian uang $(\mathrm{Y})$. pemodelan dengan confirmatory factor analysis (CFA) atau model penuh (full model) dengan structural equation modeling (SEM) akan menjumpai dengan interpretasi dari loading factor.

Hasil Loading Factor Outner Model :

\begin{tabular}{|c|c|c|c|}
\hline Variabel & Indikator & Rule of Thumb & Loading Factor \\
\hline $\begin{array}{l}\text { Akuntansi } \\
\text { Forensik }\left(\mathrm{X}_{\mathrm{l}}\right)\end{array}$ & $\begin{array}{l}\mathrm{AF} 1 \\
\mathrm{AF} 2 \\
\mathrm{AF} 3 \\
\mathrm{AF} 4 \\
\mathrm{AF} 5 \\
\mathrm{AF} 6 \\
\mathrm{AF} 7\end{array}$ & \multirow{4}{*}{$>0.6$} & $\begin{array}{l}0.665 \\
0.717 \\
0.724 \\
0.814 \\
0.637 \\
0.779 \\
0.688\end{array}$ \\
\hline $\begin{array}{l}\text { Audit Investigatif } \\
\left(\mathrm{X}_{2}\right)\end{array}$ & $\begin{array}{l}\text { AI1 } \\
\text { AI2 } \\
\text { AI3 } \\
\text { AI4 } \\
\text { AI5 } \\
\text { AI6 } \\
\text { AI7 } \\
\text { AI8 } \\
\text { AI9 } \\
\text { AI10 } \\
\text { AI11 } \\
\text { AI12 } \\
\text { AI13 } \\
\text { AI14 } \\
\text { AI15 }\end{array}$ & & $\begin{array}{l}0.631 \\
0.700 \\
0.386 \\
0.780 \\
0.721 \\
0.636 \\
0.406 \\
0.524 \\
0.623 \\
0.749 \\
0.721 \\
0.419 \\
0.627 \\
0.738 \\
0.583\end{array}$ \\
\hline Data Mining $\left(\mathbf{X}_{3}\right)$ & $\begin{array}{l}\text { DM1 } \\
\text { DM2 } \\
\text { DM3 } \\
\text { DM4 }\end{array}$ & & $\begin{array}{l}0.864 \\
0.903 \\
0.845 \\
0.904\end{array}$ \\
\hline $\begin{array}{l}\text { Pendeteksian } \\
\text { TPPU (Y) }\end{array}$ & $\begin{array}{l}\text { TPPU1 } \\
\text { TPPU2 } \\
\text { TPPU3 }\end{array}$ & & $\begin{array}{l}0.827 \\
0.894 \\
0.664\end{array}$ \\
\hline Kode Etik (M) & $\begin{array}{c}\mathrm{KE} 1 \\
\mathrm{KE} 2 \\
\mathrm{KE} 3 \\
\mathrm{KE} 4 \\
\mathrm{KE} 5 \\
\mathrm{KE} 6 \\
\mathrm{KE} 7 \\
\mathrm{KE} 8 \\
\mathrm{KE9} \\
\mathrm{KE} 10\end{array}$ & & $\begin{array}{l}0.864 \\
0.769 \\
0.761 \\
0.758 \\
0.710 \\
0.719 \\
0.391 \\
0.881 \\
0.783 \\
0.797\end{array}$ \\
\hline
\end{tabular}

Kriteria reliabilitas dalam penelitian ini yaitu indikator reliability dengan parameter loading factor dan internal concistency reliability dengan parameter loading concistency reliability. hasil uji kriteria indikator reliability dan internal concistency reliability.

Hasil Loading Factor dan Composite Reliability Outer Model :

\begin{tabular}{|c|c|c|c|}
\hline Variabel & Rule of Thumb & $\begin{array}{l}\text { Loading } \\
\text { Factior }\end{array}$ & $\begin{array}{l}\text { Composite } \\
\text { Reliabiht }\end{array}$ \\
\hline Akuntansi Forensik $\left(X_{Y}\right)$ & \multirow{5}{*}{$>0.6$} & 0.720 & 0.843 \\
\hline Audit Investigatif $\left(X_{\mathrm{S}}\right)$ & & 0.629 & 0.885 \\
\hline Dota Wining (X?) & & 0.879 & $0.90 ?$ \\
\hline Pendeteksian TPPU (Y) & & 0.801 & 0.911 \\
\hline Kode Etik (M) & & 0.754 & 0.713 \\
\hline
\end{tabular}

Kriteria validitas dalam penelitian ini yaitu convergent validity menggunakan parameter Averange Variance Extracted (AVE) dan Discriminant Validity menggunakan parameter perbandingan akar kuadrat AVE dengan korelasi atar kontruk laten.

Hasil Convergent Validity dan Discrimination Validity:

\begin{tabular}{|c|c|c|c|c|c|c|}
\hline Variabel & $\begin{array}{l}\text { Rule of } \\
\text { thumb }\end{array}$ & $\begin{array}{l}\text { Akuntansi } \\
\text { forensik }\end{array}$ & $\begin{array}{c}\text { Audit } \\
\text { Investigatif }\end{array}$ & \begin{tabular}{|c|} 
Doto \\
mining
\end{tabular} & TPPU & $\begin{array}{c}\text { Kode } \\
\text { Etik }\end{array}$ \\
\hline $\begin{array}{l}\text { Akuntansi } \\
\text { forensik }\end{array}$ & \multirow{5}{*}{$\begin{array}{l}\text { Akar } \\
\text { kuadrat } \\
\text { AVE > } \\
\text { Akar } \\
\text { kuadrat } \\
\text { antar } \\
\text { konstruk }\end{array}$} & 0.720 & 0.742 & 0.556 & 0.569 & 0.653 \\
\hline $\begin{array}{l}\text { Audit } \\
\text { Investigasi }\end{array}$ & & 0.742 & 0.629 & 0.477 & 0.571 & 0.643 \\
\hline Data mining & & 0.556 & 0.477 & 0.879 & 0.434 & 0.351 \\
\hline TPPU & & 0.569 & 0.571 & 0.434 & 0.801 & 0.447 \\
\hline Kode Etik & & 0.653 & 0.643 & 0.351 & 0.447 & 0.754 \\
\hline Parameter & $\begin{array}{l}\text { Rule of } \\
\text { thumb }\end{array}$ & $\begin{array}{c}\text { Akuntansi } \\
\text { forensik }\end{array}$ & $\begin{array}{c}\text { Audit } \\
\text { Investigasi }\end{array}$ & $\begin{array}{c}\text { Doto } \\
\text { mining }\end{array}$ & TPPU & $\begin{array}{c}\text { Kode } \\
\text { Etik }\end{array}$ \\
\hline $\begin{array}{l}\text { Averange } \\
\text { Variance } \\
\text { Extracted } \\
\text { (AVE) }\end{array}$ & $>0.5$ & 0.518 & 0.395 & 0.773 & 0.641 & 0.569 \\
\hline
\end{tabular}

\section{Hasil Uji Inner Model}

Pengukuran bagian dalam disebut juga sebagai model struktural. Model struktural adalah model yang menghubungkan antar variabel laten. Evaluasi inner model dilakukan dengan melihat :

- Adjusted R-square,

- Effect size $\left(F^{2}\right)$,

- $Q^{2}$ Predictive relevance,

- $q^{2}$ Predictive relevance,

- $A P C$,

- $A R S$,

- $A A R S$,

- $A V I F$,

- $A F V I F$, 
- Goodness Tenenhenaus,

- RSCR,

- $\quad S S R$,

- $N L B C D R$,

- Signifikansi.

\section{Hasil Uji Inner Model :}

\begin{tabular}{|c|c|c|c|}
\hline Kriteria & Rule of Thumb & Hasil & Keterangan \\
\hline Adjusted $\mathrm{R}^{-}$ & $\begin{array}{c}\leq 0.70 \text { (kuat): } \leq 0.45 \\
\text { (moderate): } \leq 0.25 \text { (lemah) }\end{array}$ & 0.490 & Kuat \\
\hline $\begin{array}{l}\text { Average Path Coefficient } \\
\text { (APC) }\end{array}$ & P-VALUE $\leq 0.05$ & 0.048 & Temenuhi \\
\hline Average $R$ square (ARS) & P-VALUE $\leq 0.05$ & 0.001 & Terpenuhi \\
\hline $\begin{array}{l}\text { Average Adjusted R } \\
\text { square (AARS) }\end{array}$ & P-VALUE $\leq 0.05$ & 0.001 & Terpenuhi \\
\hline $\begin{array}{l}\text { Average Block VIF } \\
\text { (AVIF) }\end{array}$ & $\begin{array}{c}\leq 3.3 \text { namun nilai } \leq 5 \text { masih } \\
\text { dapat diterima }\end{array}$ & 2924 & Terpenuhi \\
\hline $\begin{array}{l}\text { Average Full Collinearity } \\
\text { VIF (AFVIF) }\end{array}$ & $\begin{array}{c}\leq 3.3 \text { namun nilai } \leq 5 \text { masih } \\
\text { dapat ditenima }\end{array}$ & 2.401 & Temenuhi \\
\hline Tenenhaus $\mathrm{GoF}(\mathrm{GoF})$ & $\begin{array}{c}\geq 0.10 \text { (kecil): } \geq 0.25 \\
\text { (menengah): } \geq 0.36 \text { (besar) }\end{array}$ & 0.499 & Besar \\
\hline $\begin{array}{l}\text { Sympson's Paradox Ratio } \\
\text { (SPR) }\end{array}$ & $\begin{array}{c}\text { Idealnya }=1, \text { namun nilai } ? \\
0.7 \text { masih dapat ditenima }\end{array}$ & 0.800 & Terpenuhi \\
\hline $\begin{array}{l}\text { R square Contribution } \\
\text { Ratio (RSCR) } \\
\end{array}$ & $\begin{array}{c}\text { Idealnya }=1 \text {, namun nilai } \geq \\
0.9 \text { masih dapat ditenima }\end{array}$ & 0.927 & Terpenuhi \\
\hline $\begin{array}{l}\text { Statistical Suppression: } \\
\text { Ratio (SSR) }\end{array}$ & $\begin{array}{c}\text { Idealnya }=1, \text { namun nilai } ? \\
0.7 \text { masih dapat ditenima }\end{array}$ & 1.000 & Terpenuhi \\
\hline $\begin{array}{l}\text { Nonlinear bivariate } \\
\text { causality direction ratio } \\
\text { (NLBCDR) }\end{array}$ & $\begin{array}{c}\text { Idealnya }=1, \text { namun nilai } \geq \\
0.7 \text { masih dapat ditenima }\end{array}$ & 1.000 & Terpenuhi \\
\hline$Q^{-}$Predictive relevance & $\begin{array}{c}Q^{2}>0 \text { (mempunyai } \\
\text { predictive relevarce), } Q^{-}<0 \\
\text { (tidak mempunyai predictive } \\
\text { relevarce) }\end{array}$ & 0.485 & $\begin{array}{l}\text { Model } \\
\text { Mempunyai } \\
\text { Predictive } \\
\text { Relevarce }\end{array}$ \\
\hline
\end{tabular}

\section{Hasil Uji Effect Size dan Full Collinerarity} VIF

Uji effect size dilakukan untuk mengetahui besarnya proporsi variance variabel eksogen terhadap variabel endogen.

Hasil Effect Size:

\begin{tabular}{|c|c|c|c|c|}
\hline Pengujain & Yariabel & $\begin{array}{l}\text { Rule of } \\
\text { Thumb }\end{array}$ & Hasil & Keterangan \\
\hline \multirow{5}{*}{ Effect Size } & Alkuntantsi forensik & \multirow{5}{*}{$\begin{array}{c}\geq 0.01 \\
(\text { kecil): } \\
\geq 0.15 \\
\text { (menengah) } \\
\text { dart } \geq 0,35 \\
\text { (besar) }\end{array}$} & 0.154 & Menengah \\
\hline & Audit inlestigatif & & 0.042 & Kecil \\
\hline & Data mining & & 0.043 & Kecil \\
\hline & $\begin{array}{l}\text { Interaksi knde etik dengan } \\
\text { audit investigatif }\end{array}$ & & 0.115 & Menengah \\
\hline & $\begin{array}{l}\text { Interaksi kinde etik dengan } \\
\text { data minging }\end{array}$ & & 0.216 & Menengah \\
\hline
\end{tabular}

\section{Uji Hipotesa dan Full Model}

Pengujian hipotesis dilakukan untuk membuktikan kebenaran dugaan penelitian atau hipotesis. Pengujian ini dapat dilihat dari hasil korelasi antar konstruk pada output koefisien jalur dan tingkat signifikansinya.
Model structural :

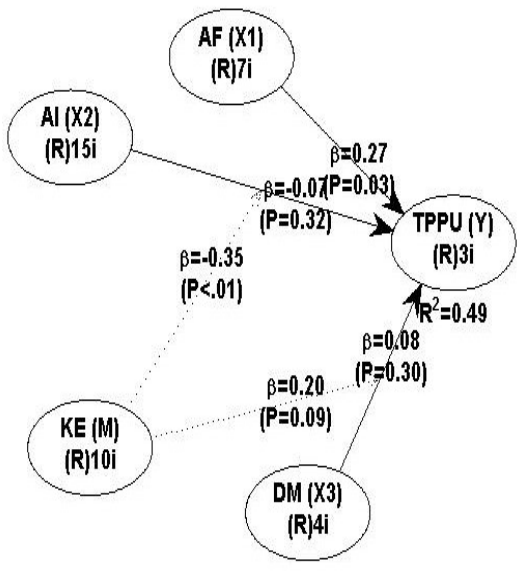

Persamaan model struktural :

TPPU $=0.27 \mathrm{AF}-0.07 \mathrm{AI}+0.08 \mathrm{DM}+$ $0.35 \mathrm{AI}^{*} \mathrm{KE} \times 0.20 * \mathrm{KE}+\varepsilon$.

Hasil output :

\begin{tabular}{|c|c|c|c|}
\hline Hubungan & $\begin{array}{c}\text { Koefisien } \\
\text { jalur }\end{array}$ & P Value & Keterangan \\
\hline Uji Parsial & & & \\
\hline $\begin{array}{c}\text { Akuntansi Forensik } \rightarrow \text { Pendeteksian } \\
\text { dugaan tindak pidana pencucian uang }\end{array}$ & 0.27 & 0.03 & Signifikan \\
\hline $\begin{array}{c}\text { Audit Investigatif } \rightarrow \text { Pendeteksian } \\
\text { dugaan tindak pidana pencucian uang }\end{array}$ & -0.07 & 0.32 & $\begin{array}{c}\text { Tidak } \\
\text { Signifikan }\end{array}$ \\
\hline $\begin{array}{c}\text { Data mining } \rightarrow \text { Pendeteksian dugaan } \\
\text { tindak pidana pencucian uang }\end{array}$ & 0.08 & 0.30 & $\begin{array}{c}\text { Tidak } \\
\text { Signifikan }\end{array}$ \\
\hline Uji Interaksi & & & \\
\hline $\begin{array}{c}\text { Interaksi Kode Etik dengan Audit } \\
\text { Invetsigatif } \rightarrow \text { Pendeteksian dugaan } \\
\text { tindak pidana pencucian uang }\end{array}$ & -0.35 & 0.008 & Signifikan \\
\hline $\begin{array}{c}\text { Interaksi Kode Etik dengan Data } \\
\text { Mining Pendeteksian dugaan } \\
\text { tindak pidana pencucian uang }\end{array}$ & 0.20 & 0.09 & Signifikan \\
\hline
\end{tabular}

\section{Uji Parsial}

a. Pengaruh akuntansi forensik terhadap pendeteksian dugaan tindak pidana pencucian uang memiliki nilai koefisien sebesar 0.27 dengan $p$-value sebesar 0.03 yang berarti bahwa akuntansi forensik berpengaruh signifikan positif terhadap pendeteksian dugaan tindak pidana pencucian uang. Hal ini menunjukan bahwa akuntansi forensik yang didasarkan pada konsep pelanggaran hukum, penghitugan kerugian dan hubungan sebab akibat dapat berfungsi dan efektif untuk mendeteksi terjadinya kecurangan/ fraud dan tindak pidana pencucian uang.

b. Pengaruh audit investigatif terhadap pendeteksian dugaan tindak pidana 
pencucian uang memiliki nilai koefisien sebesar - 0.07 dengan $p$-value sebesar 0.32 yang berarti bahwa audit investigatif tidak berpengaruh terhadap pendeteksian dugaan tindak pidana pencucian uang. Hal ini menunjukan bahwa dalam mendeteksi terjadinya tindak pidana pencucian uang, audit investigatif bukan merupakan satusatunya metode yang digunakan oleh para analis dan pemeriksa pada PPATK dalam mendeteksi terjadinya tindak pidana pencucian uang.

c. Pengaruh data mining terhadap pendeteksian dugaan tindak pidana pencucian uang memiliki nilai koefisien sebesar 0.08 dengan $p$-value sebesar 0.30 yang berarti bahwa data mining tidak berpengaruh terhadap pendeteksian dugaan tindak pidana pencucian uang. Hal ini menunjukan bahwa pemanfaatan data mining, belum menjadi menjadi satu satunya sumber informasi yang digunakan oleh para analis dan pemeriksa transaksi keuangan untuk memprediksi maupun mendeteksi terjadinya tindak pidana pencucian uang.

\section{Uji Interaksi :}

a. Pengaruh audit investigatif terhadap pendeteksian dugaan tindak pidana pencucian uang yang dimoderasi oleh kode etik adalah signifikan positif dengan nilai $p$-value sebesar 0.008 dan nilai koefisien jalur sebesar -0.35 disebut dengan moderasi murni (pure moderator). Hal ini artinya bahwa pengaruh audit investigatif terhadap pendeteksian dugaan tindak pidana pencucian uang hanya dimoderasi oleh variabel kode etik, tidak ada variabel pemoderasi lainnya dan variabel kode etik memperkuat pengaruh tersebut.

b. Pengaruh data mining terhadap pendeteksian dugaan tindak pidana pencucian uang uang yang dimoderasi oleh kode etik adalah signifikan positif dengan nilai $p$ - sebesar 0.16 dan nilai koefisien jalur sebesar 0.15 moderasi murni (pure moderator). Hal ini artinya bahwa pengaruh data mining terhadap pendeteksian dugaan tindak pidana pencucian uang hanya dimoderasi oleh variabel kode etik, tidak ada variabel pemoderasi lainnya dan variabel kode etik memperkuat pengaruh tersebut.

\section{PEMBAHASAN}

\section{Pengaruh akuntansi forensik terhadap pendeteksian dugaan tindak pidana pencucian uang}

Bahwa disiplin ilmu akuntansi forensik berpengaruh signifikan terhadap pendeteksian dugaan tindak pidana pencucian uang. Akuntansi forensik merupakan keterpaduan dari berbagai ilmu yaitu akuntansi, audit dan hukum yang dikonsepkan dalam penelitian ini melalui tiga dimensi yaitu terdiri dari pelanggaran hukum, penghitungan kerugian dan mengetahui hubungan kausalitas atau sebab akibat. Perkembangan akuntansi forensik di Indonesia saat ini semakin meluas.

\section{Pengaruh audit investigatif terhadap pendeteksian dugaan tindak pidana pencucian uang}

Bahwa audit investigatif tidak berpengaruh signifikan terhadap pendeteksian dugaan tindak pidana pencucian uang. Meskipun pelaku berupaya memberi kesan bahwa ia tidak terlibat (modus pencucian uang), harus ada aliran uang atau dana menuju tempat tujuan akhir. Naluri pelaku fraud inilah yang melandasi tehnik audit investigatif follow the money. Mengikuti jejak-jejak yang ditinggalkan aliran dana inilah yang dilakukan penyidik atau akuntan forensik dalam teknik follow the money.

\section{Pengaruh data mining terhadap pendeteksian dugaan tindak pidana pencucian uang}

Bahwa data mining tidak berpengaruh terhadap pendeteksian dugaan tindak pidana pencucian uang. Meskipun secara teori audit bahwa data mining dianggap efektif dalam mendeteksi terjadinya fraud, namun berdasarkan penelitian saat ini tidak signifikan diterapkan di dalam mendeteksi tindak pidana pencucian uang.

Peran kode etik sebagai pemoderasi atas pengaruh audit investigatif terhadap pendeteksian dugaan tindak pidana pencucian uang 
Bahwa kode etik memoderasi secara signifikan atas pengaruh audit investigatif terhadap pendeteksian dugaan tindak pidana pencucian uang. kode etik memoderasi dengan kuat (Pure Moderator). Pure Moderator adalah variabel yang memoderasi hubungan antara variabel independen dan variabel dependen dimana variabel moderasi murni berinteraksi dengan variabel independen tanpa menjadi varaibel independen.

\section{Peran kode etik sebagai pemoderasi atas pengaruh data mining terhadap pendeteksian dugaan tindak pidana pencucian uang}

Bahwa kode etik memoderasi atas pengaruh data mining terhadap pendeteksian dugaan tindak pidana pencucian uang secara positif dan signifikan. Hasil penelitian ini juga menunjukan bahwa kode etik memoderasi kedua variabel dengan kuat (Pure Moderator), artinya bahwa variabel yang memoderasi hubungan antara variabel independen dan variabel dependen berinteraksi dengan variabel independen tanpa menjadi varaibel independen. Hal ini berarti bahwa dalam penelitian ini tidak ada variabel lain yang mampu memoderasi pengaruh atas data mining terhadap pendeteksian dugaan tindak pidana pencucian uang selain kode etik.

\section{Kesimpulan, Keterbatasan, dan Implikasi Hasil Penelitian}

1) Akuntansi forensik berpengaruh signifikan terhadap pendeteksian dugaan tindak pidana pencucian uang. Hal ini berarti bahwa dalam segitiga akuntansi forensik yang terdiri dari kerugian, permasalahan hukum dan hubungan kausalitas diperlukan dalam pendeteksian terjadinya tindak pidana pencucian uang sehingga para analis dan pemeriksa transaksi keuangan PPATK dipandang perlu mempunyai keahlian bidang akuntansi dan hukum untuk membantu para aparat penegak hukum dalam mengungkap setiap jenis tindak pidana dengan motif ekonomi. Selain itu juga untuk mempermudah dalam membantu proses penegakan hukum mengidentifikasi bukti-bukti pidana dalam persidangan di pengadilan.

2) Audit investigatif tidak berpengaruh terhadap pendeteksian dugaan tindak pidana pencucian uang, setidaknya terdapat beberapa hal sebagai penyebab antara lain sebagai berikut:

a) Dalam penelitian ini peneliti tidak menentukan kriteria responden berdasarkan latar belakang pendidikan, masa dinas dan pengalaman kerja sehingga diperoleh jawaban yang bervariasi.

b) Merujuk pada pasal 40 huruf d UU 8/ 2010, dalam melaksanakan tugas sebagaimana dimaksud dalam Pasal 39, PPATK mempunyai fungsi sebagai berikut: "analisis atau pemeriksaan laporan dan informasi Transaksi Keuangan yang berindikasi tindak pidana Pencucian Uang dan/atau tindak pidana lain sebagaimana dimaksud dalam Pasal 2 ayat". Hal ini berarti bahwa dalam mendeteksi terjadinya tindak pidana pencucian uang dilakukan melalui 2 (dua) proses pendekatan yaitu proses analisis dan proses pemeriksaan terhadap transaksi keuangan yang mencurigakan.

c) Merujuk pada Peraturan Kepala PPATK 3 Tahun 2017 tentang Organisasi dan Tata Kerja telah diatur secara tegas tentang pembagian tugas antara analis dan pemeriksa transaksi keuangan dalam pendeteksian dugaan tindak pidana pencucian uang.

3) Data mining tidak berpengaruh terhadap pendeteksian dugaan tindak pidana pencucian uang. Penyebab tidak berpengaruhnya data mining terhadap pendeteksian dugaan tindak pidana pencucian uang disebabkan antara lain sebagai berikut :

a) Data dan informasi yang dikelola oleh PPATK, tidak menjadi satu-satunya sumber data yang digunakan oleh para analis dan pemeriksa transaksi keuangan untuk memprediksi dan mendeteksi terjadinya tindak pidana pencucian uang.

b) Saat ini PPATK masih terus mengembangkan sistem teknologi informasi guna mendukung 
pelaksanaan tugas dan wewenang PPATK dalam mencegah dan memberantas tindak pidana pencucian uang.

c) PPATK secara beratahap dan berkelanjutan saat ini masih melakukan interconnectivity data baik yang bersumber dari instansi pemerintah maupun swasta berdasarkan ketentuan Peraturan Pemerintah Republik Indonesia Nomor 2 Tahun 2016 Tentang Tata Cara Penyampaian Data Dan Informasi Oleh Instansi Pemerintah Dan/Atau Lembaga Swasta Dalam Pencegahan Dan Pemberantasan Tindak Pidana Pencucian Uang.

4) Kode etik memoderasi pengaruh audit investigatif terhadap pendeteksian dugaan tindak pidana pencucian uang. Dalam penelitian ini kode etik memoderasi dengan kuat (Pure Moderator). Kode etik etik telah melekat pada diri individu para analis dan pemeriksa transaksi keuangan yang mempunyai peran penting menjaga objektifitas dan kualitas hasil analisis dan hasil pemeriksaan PPATK.

5) Kode etik memoderasi pengaruh data mining terhadap pendeteksian dugaan tindak pidana pencucian uang. Hasil penelitian menunjukan bahwa kode etik memoderasi kedua variabel dengan kuat (Pure Moderator). Hal tersebut disebabkan karena dalam operasionalisasi atas pemanfaatan data dan informasi yang dikelola oleh PPATK para analis dan pemeriksa transaksi keuangan berkomitmen dan menjunjung tinggi terhadap nilai-nilai kode etik, khususnya pada nilai kerahasiaan.

\section{Keterbatasan Penelitian}

1) Populasi sekaligus menjadi sampel dalam penelitian ini adalah para analis dan pemeriksa transaksi keuangan PPATK, dalam penentuan responden tidak dibatasi dengan kriteria sampel misalnya masa dinas, pengalaman sehingga perolehan datanya variatif.

2) Penelitian dilakukan pada saat terjadi pandemic Covid-19 dan penerapan Pembatasan Sosial Berskala Besar (PSBB) di wilayah DKI Jakarta dan kantor PPATK menerapkan system kerja dari rumah (Work From Home) sehingga tidak memungkinkan untuk dilakukan konfirmasi hasil penelitian ini kepada para responden.

3) Pembahasan model hanya terbatas pada ketiga variabel independent, satu variabel moderasi dan satu variabel dependent saja.

\section{Saran}

1) Untuk pengembangan penelitian dibidang akuntansi, khususnya terkait dengan akuntansi forensik, audit investigatif dan data mining terhadap pendeteksian dugaan tindak pidana pencucian uang dengan kode etik sebagai pemoderasi.

2) PPATK dapat perluasan penerapan teknik audit investigatif dapat dilakukan oleh analis dalam pendeteksian dugaan tindak pidana pencucian uang.

3) PPATK dapat menjadi fusion centre sehingga akan memudahkan para analis dan pemeriksa dalam melakukan prediksi, ektraksi dari pemanfaatan dari bigdata dalam rangka melakukan tracking dan profiling terhadap pihak- pihak yang terindikasi melakukan kejahatan.

\section{Daftar Pustaka}

ACFE, \& Global, 2014 Fraud Study. (2014). Report To The Nations On Occupational Fraud And Abuse.

Alkostar, A. (1994). White Collar Crime dan Corporate Crime. Jurnal Hukum IUS QUIA IUSTUM, 1(2), 3-8. https://doi.org/10.20885/iustum.vol1.iss2 .art1

Ardiansyah, A., Purnamasari, P., \& Gunawan, H. (2018). Penerapan Akuntansi Forensik dan Audit Investigasi terhadap Pendeteksian Fraud Asset Misappropriation ( Studi Kasus pada Badan Pengawasan Keuangan dan Pembangunan Pusat ). 2, 695-701.

Ardiyani, S., \& Utaminingsih, N. S. (2015). Analisis determinan financial statement melalui pendekatan fraud triangle. Accounting Analysis Journal, 4(1).

Deden Teguh Pribadi, 2016. (2016). Pengaruh Kompetensi Auditor Forensik 
Terhadap Proses Penginvestigasian Kasus Tindak Pidana Korupsi Universitas Pendidikan Indonesia repository.upi.edu perpustakaan.upi.edu. 1-19.

Dewi Yuniarti Rozali, R. (2015). Teknik Audit Investigatif Dalam Pengungkapan Money Laundering Berdasarkan Perspektif Akuntan Forensik. In Jurnal Riset Akuntansi dan Keuangan (Vol. 3). https://doi.org/10.17509/jrak.v3i1.6605

Dwi Ratmono, Yunita ( 2017). Dapatkah Teori Fraud Triangle Menjelaskan Kecurangan Dalam Laporan Keuangan? Jurnal Akuntansi dan Auditing Volume 14/No. 2 Tahun 2017: 100-117. Departemen Akuntansi Fakultas Ekonomika dan Bisnis Universitas Diponegoro

Ghozali dan Latan. (2012). Buku Konsep, Teknik dan Aplikasi SmartPLS M3. Semarang: Badan Penerbit Universitas Diponegoro.

Husein, Y. (2007). Rezim Anti Pencucian Uang. Jakarta: PPATK.

Karamoy, H., \& Wokas, H. R. N. (2006). Pengaruh Independensi Dan Profesionalisme, Dalam Mendeteksi Fraud Pada Auditor Internal Provinsi Sulawesi Utara.

Karyono, \& Staf pengajar STAN dan Fakultas Ekonomi UBINus, J. (2002). Fraud auditing. The Winners, 3(2), 150-160.

Lidyah, R. (2016). Korupsi Dan Akuntansi Forensik. In I-Finance (Vol. 2).

Mark F. Zimbelman,Conan C Albercht, W. Steve Albecht dan Chad O. Albrecht (2014). Forensik Accounting, Jakarta : Salemba Empat, Edisi keempat

Ocansey, E. O. N. D., \& Sc, M. (2017). Forensik Accounting and the Combating of Economic and Financial Crimes in Ghana. 13(31), 379-393. https://doi.org/10.19044/esj.2017.v13n31 p379

PPATK. (2010). Peraturan Kepala Pusat Pelaporan dan Analisis Transaksi Keuangan Nomor: PER05A/1.01/PPATK/08/10. (35). Retrieved from

www.ppatk.go.id/backend/assets/uploads /20161003083257.pdf

PPATK. (2018). Anti pencucian uang \& pencegahan pendanaan terorisme. Bulletin Statistik APUPPT, 105/THN IX.

Rizki, B. F., Purnamasari, P., \& Oktaroza, M. L. (2016). Pengaruh Akuntansi Forensik dan Audit Investigasi terhadap Pendekteksian White Collar Crime. In Prosiding Akuntansi (Vol. 421).

Sugiyono, 2016. Metedologi Penelitian Kualitatif, Kuantitatif dan R\&D, Bandung : Alfabeta.

Siddiq, F. R., Achyani, F., \& Zulfikar. (2017). Fraud Pentagon Dalam Mendeteksi Financial Statement. Seminar Nasional Dan The 4th Call for Syariah Paper, 114. Retrieved from http://hdl.handle.net/11617/9210

Sarsiti (2014). Analisis Pengaruh Penerapan Etika Dan Peningkatan Profesionalisme Auditor Terhadap Kualitas Auditor Internal. Jurnal Ekonomi dan Kewirausahaan Vol. 14, No. 2, Oktober 196 2014: 195 - 206.

Tri Maulidiastuti, Suratno, M. Y. (2018). Analisis peran akuntansi forensik, data mining, continuous auditing, terhadap pendeteksian fraud serta Relevansinya pada pencegahan fraud (Vol. 3). Jurnal Ekobisman Vol 3. NO. 2 DESEMBER 2018.

Tuanakotta, Theodorus M (2010). Audit Forensik dan Audit Investigatif. Jakarta : Salemba Empat .

Undang-undang nomor 8 Tahun 2010 tentang Pencegahan dan Pemberantasan Tindak Pidana Pencucian Uang.

Wolfe, D. T., \& Hermanson, D. R. (2004). The Fraud Diamond: Considering the Four Elements of Fraud: Certified Public Accountant. The CPA Journal, 74(12), 38-42. https://doi.org/DOI:

Wahyuni dan Gideon Setyo Budiwitjaksono. (2017). Fraud Triangle Sebagai Pendeteksi Kecurangan Laporan Keuangan Jurnal Akuntansi/Volume XXI, No. 01, Januari 2017: 47-61 47 
Tri Puji Raharjo, Syahril Djaddang, Edy Supriadi: Peran Kode Etik Atas Pengaruh Akuntansi Forensik, Audit Investigatif dan Data Mining Terhadap Pendeteksian Dugaan Tindak Pidana Pencucian Uang

Yudi, K. (2015). Pemberantasan Tindak Pidana Pencucian Uang. Jakarta: Thafamedia.

https://nasional.kompas.com/read/2013/10/16 /1034132/PPATK.Aliran.Dana.Akil.Moc htar.Lebih.dari.Rp.10.Miliar. Artikel ini telah tayang di Kompas.com dengan judul "PPATK: Aliran Dana Akil Mochtar Lebih dari Rp 10 Miliar", , Penulis : Indra
Akuntono diakses pada tanggal 22 Desember 2019.

http://www.ppatk.go.id/siaran_pers/read/808/ indonesia-resmi-menjadi-observerfinancial-action-task-force.html, Indonesia Resmi Menjadi Observer Financial Action Task Force, 29 Juni 2018, 17:47 WIB, diakses pada tanggal 23 Desember 2019. 